\title{
PENSAR EN ESPAÑOL DESDE AMÉRICA. EL ENSAYO COMO ESCRITURA DE UNA INDEPENDENCIA INCONCLUSA
}

\author{
Fernando AínsA \\ CRICCAL, Universidad de La Sorbona-París 3
}

\begin{abstract}
Resumen: Desde los primeros momentos de la Independencia americana son evidentes los esfuerzos por asegurar que a la emancipación política siga una mental. Se trata así de "inventar" un pensamiento "original” (Simón Rodríguez) y elaborar una filosofía propia y enraizada basada en las "necesidades" de cada época y cada país (Juan Bautista Alberdi), ajena a todo "vasallaje" (Esteban Echevarría) y reivindicando la autonomía cultural americana (Andrés Be1lo). El ensayo será la herramienta privilegiada de esta búsqueda.
\end{abstract}

Palabras clave: ensayo, autenticidad, invención, Independencia, identidad.

Abstract: Since the earliest times of Latin American Independence, there are obvious efforts to ensure that the political emancipation would be followed by a liberation of the mentalities. The aim is to "invent" an "original" thought (Simón Rodríguez) and to develop an own, deeply rooted philosophy, based on the "needs" of each period and each country (Juan Bautista Alberdi), foreign to any "vassalage" (Esteban Echevarría) and claiming the autonomy of American culture (Andrés Bello). Essays will be the privileged tools for this search.

Keywords: essay, authenticity, invention, Independence, identity.

No por azar, el más indefinido de los géneros literarios —el ensayo- ha sido tradicionalmente el más representativo e idóneo para reflejar la plural y compleja, cuando no contradictoria, realidad hispanoamericana. Género incitante, polémico, paradójico, problemático, pero básicamente dialogante, el ensayo cubre una parte amplia del spectrum semántico de un continente que desde su incorporación al imaginario occidental ha provocado interrogantes y reflexiones, pero también sugerentes aperturas interculturales.

“Por qué la predilección por el ensayo en nuestra América?” se preguntaba Germán Arciniegas en 1963, para recordar que muchas páginas de corte ensayístico se escribieron en el Nuevo Mundo antes de que Montaigne reflexionara sobre la alteridad americana y reconociera que "nada hay de bárbaro ni de salvaje en esas naciones; lo que ocurre es que cada cual llama barbarie a lo que es ajeno a sus costumbres". Para Arciniegas esa singularidad era evidente, ya que para el 
mundo occidental América había surgido con su geografía y sus hombres como una novedad insospechada que rompía con las ideas tradicionales. "América es ya, en sí, un problema” — nos decía Arciniegas- "un ensayo de nuevo mundo, algo que tienta, provoca, desafía a la inteligencia"1.

Género utilizado para que los europeos reflexionaran sobre la singularidad del Nuevo Mundo - como hizo el propio Montaigne en sus famosos ensayos "Los caníbales", "Los vehículos" y "De las costumbres"- esta nueva forma expresiva sirvió también a los americanos para conocerse e identificarse a sí mismos.

En Hispanoamérica, aunque se pueda hablar de proto ensayística en las Crónicas de Indias, donde se mezcla la épica con la didáctica y se funda la personalidad y la conciencia histórica del continente, es en realidad con el pensamiento crítico de la Ilustración primero, y luego en los idearios de la emancipación que el ensayo se centra en una preocupación que no ha cesado hasta hoy en día: configurar y definir la identidad hispanoamericana y la de sus respectivas naciones. A partir de entonces, el pensamiento americano se expresa a través de este género marcado por la intensa conciencia de la temporalidad histórica; reflexiona sobre la diferencia y la alteridad, sobre lo propio y lo extraño en ese inevitable "juego de espejos" entre el Viejo y el Nuevo Mundo que caracteriza la historia de las ideas en un continente enfrentado a "contradicciones y antinomias"2. $\mathrm{El}$ ensayo propicia esa "otra mirada", esa curva abierta del descentramiento de la modernidad en la que se inscribe Hispanoamérica, plasmada en la formulación de un discurso desde la periferia que Leopoldo Zea ejemplariza en Discurso desde la marginación y la barbarie (1988) y, desde otra perspectiva, Richard Morse en El espejo de Próspero. Un estudio de la dialéctica del Nuevo Mundo (1982)3, donde propone que Hispanoamérica se mire en su propio espejo y no en los "reflejos" de los Estados Unidos. Estos reflejos entre espejos los convierte J.M. Briceño Guerrero 4 en un juego revelador sobre la "segunda" identidad europea de Hispanoamérica, identidad "importada" que engloba las ideas del racionalismo, la Ilustración y la utopía social sobre un sustrato cristiano-hispánico, un complejo que aparece relativizado por el "discurso salvaje" emotivo, humorístico y en el fondo escéptico de lo vernacular americano.

Estos reflejos mutuos entre el Nuevo y el Viejo Mundo que el ensayo ha multiplicado, prolongan en el tiempo una reflexión que se ha ido ajustando y

1 G. Arciniegas, "Nuestra América es un ensayo", Con América nace la nueva historia, Bogotá, Tercer Mundo editores, 1991, 357.

2 M. Andueza, "Trayectoria y función del ensayo hispanoamericano del siglo XX", El ensayo en nuestra América. Para una reconceptualización, Actas del Coloquio Internacional sobre el ensayo en América Latina, México, UNAM, 1993, 7.

3 R. Morse en El espejo de Próspero, México, Siglo XXI, 1982.

${ }^{4}$ J. M. Briceño Guerrero, El laberinto de los tres minotauros (Caracas, Monte Ávila, 1994) reúne las tres obras fundamentales de Briceño Guerrero, La identificación americana con la Europa segunda (1977), Europa y América en el pensamiento mantuano (1981) y Discurso salvaje (1980). 
adaptando a las ideologías y corrientes estéticas de cada época, muchas veces en forma diacrónica, abordando desde diferentes ángulos temas recurrentes como el ser de América; la unidad continental; el mestizaje cultural; "el humanismo americano" 5 o las dualidades civilización/ barbarie, campo/ ciudad, evasión/ arraigo y tradición/ modernidad. En el proceso de "americanización" de la escritura ensayística las ideas de la Ilustración han desempeñado un papel fundacional.

A la vigencia de estas ideas quisiera referirme antes que nada, ya que han cobrado una renovada actualidad en el pensamiento contemporáneo post-utópico.

\section{Propiciar una relectura de la Ilustración}

En efecto, en la perspectiva del Bicentenario de la Independencia que se conmemora estos años (según los países), algunos aspectos del pensamiento de la Ilustración invitan a una relectura contemporánea de la tradición crítica y humanística del Siglo de las Luces. En esta recuperación, verdadera filiación del pensamiento actual, se inscriben las obras de publicación reciente: Reivindicación de la Ilustración. Hacia una política de compromiso radical de Stephen Bronner; L'Esprit de l'ilustration de Tzvetan Todorov y la "reinvención libertaria" del pensamiento de la Ilustración que sugiere Noam Chomsky. La reedición de dos obras fundamentales: Filosofía de la Ilustración de Ernst Cassirer y Dialéctica de la Ilustración de Theodor Adorno y Max Horkheimer, se inscriben en esta misma dirección. Porque si para Adorno "el pensamiento crítico no se detenía ante el progreso y exigía tomar partido a favor de "los residuos de libertad" y de "la humanidad real", para Noam Chomsky los valores de la Ilustración son "valores de verdad, libertad, independencia y justicia" y para Bronner "siguen con nosotros" estos pensadores que "hablaban en nombre de los humildes y despreciados"; son los que ahora apoyan "la lucha de cualquier movimiento progresista y proponen el tipo de mundo que toda persona decente desea ver. Su tarea no ha pasado de moda". La Ilustración sigue comprometida con causas progresistas que intentan desterrar prejuicios y cuestionar creencias populares arraigadas, "restregando a la sociedad a contrapelo", al decir de Walter Benjamin.

"Después de la muerte de Dios, después del hundimiento de las utopías, ¿'sobre qué base intelectual y moral queremos construir nuestra vida en común?" — se pregunta Tzvetan Todorov al emprender la búsqueda de un marco conceptual que pueda fundar el discurso y los actos del reflexionar contemporáneo ${ }^{6}$. Su búsqueda desemboca en el espíritu de la Ilustración, cuando por primera vez en la historia de la humanidad, se propuso y aceptó que el ser humano podía

5 E. Montiel en El humanismo americano. Filosofía de una comunidad de naciones (Lima, FCE, 2000) reivindica la tradición humanista de un Nuevo Mundo que se inaugura en la modernidad sin caer en una ideología complaciente que haya elaborado "un antropocentrismo laudatorio del hombre y de su capacidad transformadora" (18).

6 T. Todorov, L'Esprit des Lumières, París, Robert Laffon, 2006. 
reflexionar por sí mismo, fuera de todo dogma, autoridad y creencia apriorística. En ese regreso, Todorov ensalza la fórmula eficaz del racionalismo de Descartes y el empirismo de Locke y propugna un retorno a los olvidados ideales del Siglo de las Luces: el pensamiento crítico, la razón, la ciencia, la libertad y el principio de la duda frente a toda verdad proclamada en forma absoluta, pero, sobre todo, al lema de Rousseau: "pensar y actuar según los principios del juicio propio". Todo ello manejado en la "razón común y compartida", sometiendo al libre examen las convicciones personales y en el "diálogo argumentado" que preconizaba Condorcet. Claro está que tales principios son contrarios a todo abuso de autoridad y ejercicio abusivo del poder o de la ideología entendida como religión de dogmas inquebrantables.

Lo importante de esta relectura reivindicativa de la Ilustración es no abordarla con un exclusivo criterio historicista limitado al siglo XVIII — "siglo de la crítica”, como lo llamara Kant- sino como un alegato a favor de un modo de pensar imprescindible para abordar el presente. El Siglo de las Luces, aunque es históricamente un siglo "pasado", debe percibirse como una "actitud" ante el mundo. Los ensayistas que propician esta visión recuerdan que las ideas de la Ilustración han sido fundamentales para configurar la socialdemocracia, el laicismo, la ciencia, el cosmopolitismo, el rechazo de privilegios de clase, los compromisos republicanos, la valorización del ciudadano y la búsqueda de reformas sociales como las impulsadas por socialistas que reivindicaron esa tradición más allá del marxismo que profesaban, como Karl Kautsky, Rosa Luxemburgo, Jean Jaurès, León Blue y Ernst Bloch.

Los ideales de la modernidad que la Ilustración inaugura permitieron a la humanidad emanciparse del despotismo, la ignorancia, la barbarie y la miseria al consagrar los ideales de la razón ${ }^{7}$, han demostrado —al mismo tiempo- los límites del impulso de los países americanos. El ímpetu hacia la universalidad de la Ilustración tendió a borrar lo particular, lo fragmentario, las redes flexibles que escapan a las pretensiones absolutas de la razón.

\section{Inventamos o erramos}

En la perspectiva hispanoamericana de una revalorización de algunos de los principios del pensamiento ilustrado, debe releerse lo mejor de la tradición ensayística. Desde el momento de la Independencia, el ensayo estuvo abocado a configurar la identidad hispanoamericana y a encontrar los modelos más adecuados para afrontar los conflictos y las antinomias en que se dividía y polarizaba la sociedad. A ello contribuyó a la búsqueda de una "orijinalidad" americana que Simón Rodríguez resumió en la máxima "inventamos o erramos".

En 1828, en los albores de la independencia americana, Simón Rodríguez, el que fuera maestro de Simón Bolívar, se preguntaba: “¿Dónde iremos

\section{J. F. Lyotard, La condición posmoderna, Madrid, Cátedra, capítulos 4 y 5.}


a buscar modelos.....?", para responderse a sí mismo: "La América española es orijinal=orijinales han de ser sus Instituciones i su Gobierno = i orijinales los me-

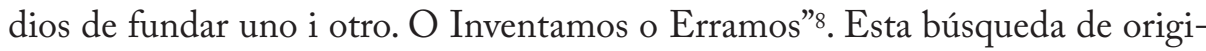
nalidad a través de la "invención" la acompañaba de una ortografía diferente y una disposición gráfica del texto más próxima a la de una partitura musical que a la de la página de un libro al usar tipos de imprenta de tamaños diversos, profusión de llaves y corchetes y al distribuir las frases en las páginas para mejor asociar palabras y conceptos?.

Frente a esta logografía ${ }^{10}-$ y más allá de su excentricidad, cercana a lo que serían las experiencias literarias vanguardistas del siglo XX o las propuestas ortográficas de Juan Ramón Jiménez con las que mantiene un curioso parentesco- el planteo de Simón Rodríguez era tan claro como consecuente: se trataba de romper con el lenguaje colonial y de crear una escritura independiente y revolucionaria ${ }^{11}$. El conjunto de su obra reflejaría ese esfuerzo para que América fuera orijinal y no una mera copia de los modelos que había heredado en el momento de la Independencia. Una orijinalidad que respondiera a la necesidad de preparar a los ciudadanos para "vivir en República" y no continuar haciendo "Repúblicas sin Ciudadanos", ya que — anotaba con cierta consternación- "en la América del Sur las Repúblicas están Establecidas pero no Fundadas". Como lo había adelantado Bolívar, Simón Rodríguez era consciente de que "a la monarquía no se podía volver", pero tampoco “a la república se podía llegar" con la creación ex-nibilo de democracias en sociedades edificadas a lo largo de tres siglos de "autoritarismo vertical de derecho divino" y sin ninguna experiencia de autogobierno ${ }^{12}$. Comprobaba, con visión premonitora, que "cambian los gobiernos pero no cambian las costumbres". Y sentenciaba: "Ese es el error de las revoluciones. Cambian las leyes pero no tocan la escuela. Tiempo perdido"13. En este planteo del autor de la famosa máxima "Inventamos o erramos" se adelantaban y resumían las que serían preocupaciones prioritarias del ensayo y la filosofía americana del siglo XIX y buena parte del siglo XX: definir lo autóctono, darle una identidad a las flamantes naciones, "inventarla" si fuera necesario, marcar las diferencias con Europa, especialmente con España y hacer de América objeto y sujeto del filosofar y de la reflexión ensayística. Sin embargo, todos ellos — hombres públicos, auténticos "intelectuales orgánicos", al modo

8 S. Rodríguez, Inventamos o erramos, Caracas, Monte Ávila, 1980, 9.

9 S. Rodríguez, Sociedades americanas. Caracas, Biblioteca Ayacucho, 150, 1990. Introducción de Juan David García Bacca, IX. "Habiendo aprendido el oficio de tipógrafo en su estadía en Baltimore, Simón Rodríguez “realzó su pericia artesanal con sus dotes pedagógicas y estéticas” lo que le permitió emplear diversos tipos de letra para resaltar ciertas palabras y frases con un énfasis digno de "una partitura musical", Introducción de J. D. García Bacca, IX.

10 A. Uslar Pietri, La isla de Robinsón, Barcelona, Seix-Barral, 1981.

11 J. Liscano, Introducción a la edición de Sociedades Americanas, o.c., 27.

12 VV. AA., Arturo Uslar Pietri, Semana del autor, Madrid, ICI, 1988, 25.

13 A. Uslar Pietri, La isla de Robinsón, o.c., 73. 
definido por Gramsci, desempeñando papeles muy diversos en las sociedades independizadas: polígrafos, políticos, hombres de acción, periodistas, conferencistas, educadores, legisladores, ministros, diplomáticos o poetas, autores de una escritura transgenérica y de variada temática ensayística- descubrirían las dificultades y las insuficiencias de una empresa más voluntarista, por no decir utópica, que practicable.

Todos, con diferentes matices, comprobarían el hecho de que, si bien se había producido una independencia política, no era tan evidente la consiguiente emancipación del pensamiento. El argentino Esteban Echeverría lo pregona abiertamente: "Ya los brazos de España no nos oprimen, pero sus tradiciones nos abruman", razón por la cual la América independiente continua "en signo de vasallaje" adornándose con las "apolilladas libreas del ropaje imperial". La conclusión resultaba clara: "Nos parece absurdo ser español en literatura y americano en política"14. Haber emancipado el cuerpo sin haber emancipado la inteligencia no servía de nada.

\section{A la búsqueda de una filosofía americana}

Años después, en la misma dirección del Dogma de la Asociación de Mayo formulado por Echeverría, el primer editorial de El Iniciador, periódico fundado en Montevideo por Andrés Lamas con el emigrado argentino Miguel Cané, recuerda las "dos cadenas" que ligaban estas provincias a España: la política y la cultural, mucho más sutil y disimulada. Por ello, si la primera fue hecha pedazos gracias a la "misión gloriosa de nuestros padres", la segunda es — según Andrés Lamas- tarea de su generación:

Hay que conquistar la independencia inteligente de la nación, su independencia civil, literaria, artística, industrial, porque las leyes, la sociedad, la literatura, las artes y la industria deben llevar como nuestra bandera, los colores nacionales, y como ella ser el testimonio de nuestra independencia y nacionalidad ${ }^{15}$.

Debe buscarse "un San Martín de la cultura" — completa Juan Bautista Alberdi- porque América quiere ser, pese al sueño frustrado de Bolívar, una y unida, pero diferente de España.

En esa dirección - la construcción de un pensamiento propio y enraizadode la que no se conoce todavía el recorrido, la lección inaugural en el Colegio de Humanidades de Montevideo en la que Alberdi presenta sus Ideas para presidir a la confección del curso de filosofía contemporánea, marca un hito fundacional. Afirma allí el autor de Predicar en desiertos y de Reacción contra el españolismo: que

14 E. Echeverría, Dogma socialista de la Asociación de Mayo (Buenos Aires, 1838). Buenos Aires, Cedal, 1979.

15 Citado por A. Zum Felde, Proceso intelectual del Uruguay, Tomo 1, "De la Colonia al Romanticismo", Montevideo, Ediciones del Nuevo Mundo, 1987, 111-112. 
"no hay una filosofía universal, porque no hay solución universal de las cuestiones que la constituyen en el fondo. Cada país, cada época, cada filósofo ha tenido su filosofía peculiar".

"Toda filosofía — agrega en una perspectiva historicista avant la lettre- ha emanado de "las necesidades más imperiosas de cada período y de cada país". Propiciando la creación de una reflexión americana, hasta ese momento inexistente, completa: "nuestra filosofía ha de salir de nuestras necesidades", necesidades que enumera como los problemas de la libertad, de los derechos y la organización pública ${ }^{16}$. La respuesta al inventario de "nuestras necesidades" que propone Alberdi —al que se considera "prócer de la emancipación mental hispanoamericana"- debía ser "esencialmente política y social en su objeto, ardiente y profética en sus instintos, sintética y orgánica en su método, positiva y realista en sus procederes, republicana en su espíritu y destinos". Para ello, América debía educarse siguiendo las pautas de la filosofía universal, aunque solo tomando de ella las doctrinas y corrientes que convinieran a su realidad. En resumen: "Filosofía americana será la que resuelva el problema de los destinos americanos". El ensayo sería una de sus mejores herramientas para lograr esa independencia.

La misión primordial del ensayo era conceptualizar la "diferencia" y definir un "ser americano". Integrar el sentimiento de pertenencia a un pasado común supuso racionalizar sentimientos y simbolizar metafóricamente estructuras profundas del subconsciente colectivo alrededor de lo que Juan Bautista Alberdi resumió en la máxima: "nuestra filosofía ha de salir de nuestras necesidades". Con ese presupuesto se propugna la panacea de una "desespañolización" del espíritu (Ignacio Ramírez) y Andrés Bello, a los términos americanistas conocidos de su Alocución a la poesía (1823) por los cuales invitaba a la poesía a dejar la "culta Europa" y dirigir su vuelo al Nuevo Mundo, insiste en 1848 en la necesaria "autonomía cultural de América":

Nuestra civilización será también juzgada por sus obras; y si se le ve copiar servilmente a la europea aún en lo que ésta tiene de aplicable, ¿cuál será el juicio que formará de nosotros un Michelet, un Guizot? Dirán, la América no ha sacudido aún sus cadenas; se arrastra sobre nuestras huellas con los ojos vendados; no respira en sus obras un pensamiento propio, nada original, nada característico; remeda las formas de nuestra filosofía y no se apropia su espíritu. Su civilización es una planta exótica que no ha chupado todavía sus jugos a la tierra que la sostiene ${ }^{17}$.

16 J. B. Alberdi, "Ideas para un curso de filosofía contemporánea”, Fuentes de la cultura latinoamericana, Vol.1, L. Zea, comp., México, FCE, 1993, 148.

17 A. Bello, Obras completas, vol. VII, Santiago de Chile, 1884. La declaración de independencia de la poesía hispanoamericana también es proclamada en la Silva a la agricultura de la zona tórrida (1826). 
Para ello hubo que romper con ciertos esquemas de dependencia que José Martí parodió décadas después en Nuestra América (1891): "éramos una máscara con los calzones de Inglaterra, el chaleco parisiense, el chaquetón de Norteamérica y la montera de España"18. En ese momento era evidente que América ya tenía su historia propia y no podía "inventarse" en permanencia; no era "un vacío que debe llenarse una y otra vez". En su ensayo, auténtico manifiesto de americanidad, recordaba que América son sus indios, pero también sus conquistadores, libertadores y civilizadores: un todo, un auténtico crisol de culturas. Se trataba, por lo tanto, de "imitar si no se puede hacer otra cosa, pero aun al imitar, inventar un tanto, adaptar", porque existe el riesgo de que en el afán por ser diferente de lo que se es, se esté negando justamente todo aquello que ya se es. Una originalidad y una "adaptación" que Carlos Arturo Torres, siguiendo el ejemplo del filósofo Bacon y su cacería de los idola fori - tópicos, supersticiones, mitos y "falsas nociones"- para poder reinterpretar la naturaleza y desacralizar, desmitoligizar y desprejuiciar un conocimiento protegido por una "clase sacerdotal", retoma esa misión desde la perspectiva del Nuevo Mundo. En Idola Fori (1910) propugna debatirse contra ideas, ideologías y formas de pensar a las que llama "verdaderas supersticiones políticas", que lejos de ayudar a la organización mental y social la congelan con "letal fuerza cataléptica". Consciente de lo arduo de su empresa, Torres considera que el sólo intentarlo, "el señalar la posibilidad de reducir a sus verdaderas proporciones de pensares falibles o caducas opiniones cuantos ya se tuvieron por canon y dogma incontrovertible de la política y de la filosofía, es despertar los aletargados estímulos del examen y exaltar el valor y las afirmaciones de la autonomía humana" ${ }^{19}$. Nada mejor que el pensamiento racional e independiente que propugnó la Ilustración para propiciar ese "despertar".

Arturo Andrés Roig recuerda como Francisco Miranda, a fines del siglo XVIII —en pleno Siglo de las Luces - ya hablaba de la necesidad de lograr una "emancipación mental" que completara la independencia política; de cómo Bolívar se lamentaba de que "nuestras manos están libres y todavía nuestros corazones padecen las dolencias de la servidumbre" y Juan Bautista Alberdi señalaba "rompimos las cadenas mediante las armas, pero nos falta quebrar otras, lo que será obra del pensamiento'"20. Por ello Roig plantea la necesidad de "una segunda independencia" que complete el proceso iniciado por la primera y rescata la idea de la "emancipación" instaurada por la Ilustración. En esta segunda independencia se debería completar la tarea inconclusa de emancipar el pensamiento, "emancipación mental" de la que dependen los viejos ideales de la

18 J. Martí, Nuestra América, Caracas, Biblioteca Ayacucho, 1977, 30.

19 C. A. Torres, Idola Fori, México, Latinoamericana. Cuadernos de Cultura latinoamericana, 96, UNAM, 1979, 7.

20 A. A. Roig, "Necesidad de una segunda Independencia", Santiago de Chile, Polis. Revista académica bolivariana, Volumen 1, 4, 2003. 
democracia participativa hoy amenazados por las formas mas groseras de la racionalidad capitalista. Se trata pues de rescatar la independencia perdida, lo mejor del pensamiento liberal depurado del economicismo capitalista.

Por ello, con el mismo apasionado énfasis, se recuerda como el ensayo inspiró denuncias de injusticias y desigualdades y ha desenvuelto el pensamiento antiimperialista o el de la filosofía de la liberación con un sentido de urgencia ideológica más persuasivo que demostrativo y donde el conocimiento del mundo no se puede separar del proyecto de transformarlo. El ensayo ha optado, en general, por una actitud militante, esa "poderosa carga estética y ética compulsiva de acción” ${ }^{21}$ que puede observarse en José Martí. “Trincheras de ideas valen más que trincheras de piedra" - aseguraba- porque en el ensayo "la prosa, centelleante y cernida, va cargada de idea".

De ahí la mayor vocación mesiánica y utópica del ensayo hispanoamericano, especialmente si se lo compara con el europeo. El eclecticismo es notorio en el ensayismo de tradición sajona y francesa. La informalidad, la soltura y distancia de la que hace gala el ensayismo inglés o el esprit del francés están lejos del énfasis programático del ensayismo hispanomericano. La tradición del inglés con su ironía y aparente despreocupación distanciada (detachment), las buenas maneras literarias (good manners), no contaba, hasta no hace mucho, con seguidores en un continente cuyo pensamiento está menos dirigido al individuo que a una colectividad (conciudadanos, nación) y donde prima un nosotros o un yo nacional sobre el yo individualista del ensayo clásico europeo.

La desiderata de proyección utópica perceptible en buena parte de la ensayística continental contrasta la realidad (el ser de América) con una aspiración (el deber ser), expresión de una tensión utópica entre lo real y lo ideal que, más que proponer modelos orgánicos y precisos, se ha manifestado como "intención" en los ensayos canónicos La utopia de América (1925) de Pedro Henríquez Ureña y Última Tule (1941) y No hay tal lugar...(1960) de Alfonso Reyes22. Si la proyección mesiánica ha podido conducir a veces a la visión grandilocuente del destino de América en ensayos como La creación de un continente (1912) de Francisco García Calderón o a las "iniciativas" de Francisco Bilbao y su propuesta de unificar el alma, el pensamiento, el corazón y la voluntad porque "la América debe al mundo una palabra [...]: esa palabra serán los brazos abiertos de la América a la tierra y la revelación de una era nueva" ${ }^{23}$, la conciencia de esa "vieja e incurable exaltación verbal de nuestra América” —según ya advertía José Carlos

21 S. Morales, "El ensayo revolucionario: José Martî", El ensayo en nuestra América. Para una reconceptualización, México, UNAM, 1993, 330.

22 H. Cerutti, ed., Utopía y nuestra América, Quito, Biblioteca Abya-Yala, 1996; América Latina: Democracia, pensamiento y acción. Reflexiones de utopía, México, CCYDEL, Plaza y Valdés, 2003; Utopía en marcha, Quito, Editorial Abya-Ayala, 2009.

23 F. Bilbao, Iniciativa de la América, Latinoamericana. Cuadernos de Cultura latinoamericana, 96, UNAM, 3, 1978, 6. Pese a su manifiesto voluntarismo, Bilbao no deja de comprobar que frente a los Estados Unidos, América Latina se presenta como "los estados desunidos". 
Mariátegui- no necesita alimentarse de "una artificiosa y retórica exageración de su presente" 24 .

El autor de Siete ensayos de interpretación de la realidad peruana (1928) consideraba que la fe de América en su provenir engendra una serie de exageraciones categóricas que deben ser acotadas, acotación que basaba en el sentido responsable y comprometido de inserción en la historicidad del ensayista que se siente éticamente "reformador" y "transformador de la sociedad". De ahí que buena parte de la producción continental insista en plantear fines sociales deseables y enunciar medios de cómo alcanzarlo, auténtico género "bisagra" entre la historia y la reflexión, punto de inflexión entre teoría y praxis 25 . "Literatura funcional" la llama José de Onís, donde el contenido impera sobre la forma y donde la misión ética del autor prima sobre cualquier otra consideración estética.

\section{Buscar la autenticidad}

Un examen de la historia del ensayo hispanoamericano desde la perspectiva de la "invención" y de ese esfuerzo por diferenciarse e independizarse de toda influencia permite rastrear una terminología que insiste en "reivindicar nuestro pasado", "fomentar valores propios", "buscar la autenticidad", "combatir las ideas foráneas", "evitar la alienación", "ser fieles a nosotros mismos", denunciando la deculturación provocada por la alienación, cuando no el imperialismo cultural y, más recientemente, combatiendo la globalización.

En su afán de autoafirmación, el pensamiento americano propone también un retorno a formas nativas de su cultura, y en algún caso llega al extremo de negar valor a la filosofía occidental glorificando lo puramente indígena. Ante esta polarizada disyuntiva excluyente, el peruano Francisco Miró Quesada descubre una dirección posible:

Latinoamérica es consciente de su inautenticidad cultural, esto es, del origen importado de su cultura. Por esta misma razón su mayor deseo es el de contribuir genuinamente en el proceso creativo de una cultura que, siéndole propia le es, paradójicamente extraña. Al mismo tiempo que acrecienta su autonocimiento, Latinoamérica va tratando de pasar de una cultura excéntrica, cuyo eje se encuentra inclinado hacia Europa, hacia una cultura concéntrica, centrada en sí misma. Este cambio de centro, no significa en modo alguno el rechazo de la cultura occidental, sino solo el deseo agudo de una genuina integración ${ }^{26}$.

24 J. C. Mariátegui, “¿Existe un pensamiento hispanoamericano?”, Fuentes de la cultura latinoamericana, vol. II, L. Zea, comp., México, FCE, 1993, 40.

25 H. Cerutti, "Hipótesis para una teoría del ensayo. Primera aproximación”, El ensayo en nuestra América. Para una reconceptualización, o.c., 23.

26 F. Miró Quesada, "El impacto de la metafísica en la ideología latinoamericana", Antología de la Filosofía Latinoamericana contemporánea, selección de L. Zea, México, Costa Amic Editor, 178. 
Abocados a la construcción de los estados nacionales y de una identidad insertada en una intersubjetividad histórica basada en herencias y raíces recuperadas, experiencias comunes y tradiciones asumidas, la filosofía, a través del género ensayo que practican Andrés Bello, Domingo Faustino Sarmiento, Juan Montalvo, Eugenio María de Hostos, José Martí o Manuel González Prada, busca forjar la imagen de colectividades nacionales.

En esta búsqueda se recapitulan los llamados "males endémicos" americanos, siguiendo el lema del Evangelio americano (1864) de Francisco Bilbao: "Conoceremos la historia para saber maldecirla" 27 , males que eran, según el polígrafo chileno, "males importados por la cultura hispánica": el fanatismo, el despotismo, la ignorancia. La aculturación y la alienación que padecía América se interpretaba como una forma de dependencia que no sólo tenía sus culpables directos en el exterior, sino también agentes colaboracionistas en el interior de los países. El fenómeno que en México se llama malinchismo, era también el de las «oligarquías locales» y el de la «burguesía aliada al capital internacional» manejado en el clásico discurso antiimperialista acuñado en las primeras décadas del siglo XX.

Eran los vendepatrías, cipayos, gusanos para unos, los "cretinos útiles» para otros, intelectuales alienados y en la medida en que una cierta clase ilustrada vivía pendiente del mimetismo cultural, podía transformarse en los rastacueros, trasplantados y la fauna de "aborígenes" americanos que viajaban por Europa y Estados Unidos admirados y boquiabiertos. Esos "descastados" que son más culpables que "nostálgicos o equivocados”, según los calificaba José Martí al distinguir entre la "falsa erudición" y la "naturaleza". Otros, eran esas "almas sin pasaporte” a las que gráficamente aludiría décadas después Victoria Ocampo, ella misma figura emblemática del cosmopolitismo porteño.

Las invariantes americanas que enumera por su parte Ezequiel Martínez Estrada son lo colonial, lo indígena, lo gauchesco, lo "aluvial", los "coágulos inasimilados que se tratan de ocultar", aunque con la importación de elementos de otros sistemas culturales, que llegaron a través de la escuela, la inmigración, el capital extranjero, el fomento económico, nuevas artes y técnicas, se hubieran tratado de "exorcisar esos lastres malignos". En la medida en que los sistemas importados carecían "de espíritu", se generaban nuevos males, concluía con tono pesimista Martínez Estrada: "una barbarie corrompida por la cultura; una cultura pegadiza y bastarda”. Tan severo diagnóstico condujo a algunos pensadores a sostener que América era un "continente enfermo"28.

27 F. Bilbao, El evangelio americano, Caracas, Biblioteca Ayacucho, 1988, 129, 85. La cita completa dice así: "Raza imbécil! de escritores, sin pensamiento propio, que mantienen la infatuación de la Europa en la injusticia, afuera! Pedagogos serviles de tiranos y de pueblos siervos, no vengáis a mancillar la inteligencia Americana! -Nosotros conoceremos la historia para saber maldecirla, para apreciar nuestra civilización Americana, para despreciar la satisfacción del error en que vives, y para venerar sus mártires!".

28 Por ejemplo, C. Zumeta en Continente enfermo (1899), F. Bulnes en El porvenir de los pueblos latinoamericanos (1899), A. Arguedas en Pueblo enfermo (1903) y C. O. Bunge Nuestra América (1903). 
Con saludable humor y fina ironía Alfonso Reyes alude en Notas sobre la inteligencia americana a esas "fatalidades concéntricas" que acosan al americano. La primera, ser un ser humano, por aquella sentencia de Calderón de que "el delito mayor del hombre es haber nacido". La segunda fatalidad era haber llegado muy tarde a un mundo viejo. En tercer lugar, "encima de las desgracias de ser humano y ser moderno, la muy específica de ser americano; es decir, nacido y arraigado en el suelo que no era el foco actual de civilización, sino una sucursal del mundo". En cuarto lugar, "era el ser latino o, en suma, de formación cultural latina". En quinto lugar "ya que se pertenece al orbe latino, nueva fatalidad dentro de él, pertenecer al orbe hispánico", donde ya se "había puesto el sol en sus dominios". Sexta fatalidad — nos dijo Reyes- el que "dentro del mundo hispánico, todavía veníamos a ser dialecto, derivación, cosa secundaria, sucursal otra vez: lo hispanoamericano, nombre que se ata con guioncito como cadena con cadena". Y como séptima fatalidad, "dentro de lo hispanoamericano", los que se lamentan haber nacido en "la zona cargada de indio". Para los mexicanos - concluía - existía una octava fatalidad: la de haber nacido en "la temerosa vecindad" de los Estados Unidos ${ }^{29}$.

Fatalidades que H.A. Murena denuncia en El pecado original de América. "Con América se da el escandaloso caso de que — salvo frustrados intentosha sido y es interpretada, inclusive por los americanos, según una clave puramente europea”, es decir, a través de la mirada, por no decir los modelos, de los otros. Estos modelos forjados por otros, al ser aplicados para definir América, no hacen sino acumular nuevos malentendidos. El americano — nos decía- rehuye mirar de frente su condición de soledad y su falta de herencia histórica y se conforma engañosamente con la exterioridad de un tradicionalismo alimentado con tópicos. Soledad que, unos años después, se convirtió en paradigma en la obra de Octavio Paz, El laberinto de la soledad (1950).

Resulta evidente que no puede repetirse que "la cultura propia de América está definitivamente individualizada, como cosa distinta de lo europeo originario y de lo indígena primitivo", como proclama con tono enfático Ricardo Rojas en Eurindia $(1924)^{30}$, ya que, como recordaría décadas después el mismo Murena: "No podemos continuar a España ni podemos continuar a los incas, porque no somos europeos ni indígenas. Somos europeos desterrados y nuestra tarea consiste en lograr que nuestra alma europea se haga con la nueva tierra" 31 . Erradicada a la periferia, Hispanoamérica se vería a sí misma viviendo en "los Balcanes de la cultura" (Carlos Fuentes), es decir, al margen de los centros culturales asociados inevitablemente con las grandes capitales europeas. Como sugería irónicamente Pablo Neruda: "Nosotros los chilenos, somos los sobrinos de

29 A. Reyes, "Notas sobre la inteligencia americana", Obras completas de Alfonso Reyes, vol. XI, México, FCE, 89.

30 R. Rojas, Eurindia: ensayo de estética sobre las culturas americanas, Buenos Aires, Cedal, 1980.

31 H. A. Murena, El pecado original de América, Buenos Aires, Sur, 1954. 
Occidente" ${ }^{32}$ En tanto que lejanía referida a un hipotético centro, el uruguayo Alberto Zum Felde se permitió la boutade, no exenta de nostalgia: "Nosotros los habitantes del Río de la Plata, vivimos en el confín del mundo”.

\section{Los limites de la originalidad}

Sin embargo, la "originalidad" y autoctonía buscada tenía un límite. Lo había percibido el propio Martí al ser consciente de que América tenía en su historia diversos componentes de los que no se podía prescindir. América no podía "inventarse" en permanencia; no era "un vacío que debe llenarse una y otra vez", como decía gráficamente. En su ensayo Nuestra América, auténtico manifiesto de americanismo, recordaba que América son sus indios, pero también sus conquistadores, libertadores y civilizadores: un todo, un auténtico crisol de culturas. Se trataba, por lo tanto, de "imitar si no se puede hacer otra cosa, pero aun al imitar, inventar un tanto, adaptar", porque existe el riesgo de que en el afán por ser diferente de lo que se es, se esté negando justamente todo aquello que ya se es.

América intenta reproducir proyectos que han pretendido ser modelos de "otros mundos", "modelos extraños a estas patrias" - como los define Leopoldo $Z_{\text {ea }}{ }^{33}$ - que se han revelado, simplemente, como "malas copias": primero como remedo de España, luego, como esfuerzos liberadores y civilizadores, aunque no hayan sido más que "importaciones" de Inglaterra, Francia o Estados Unidos. Finalmente, en pleno siglo XX, como extremos irreductibles de un espectro ideológico que va de los abiertamente revolucionarios a los conservadores, cuando no reaccionarios o dictatoriales. Estos diferentes modelos, con sus variantes y contradicciones, aparecen como intentos frustrados, esfuerzos dispersivos alimentando el "cementerio de ideologías", con que se metaforiza en una rápida sentencia la historia de las ideas de América.

En todas sus manifestaciones culturales América sigue esta desviación que va de la periferia al centro. Un proceso que si bien surge de una cierta inautenticidad inicial en la asimilación y manejo de la subordinación occidental, está seguido de un esfuerzo por sobrepasarla en una autenticidad progresivamente más creativa. Un camino zigzagueante que va de un desplazamiento inicial de su origen a una decidida participación en el proceso occidental.

\section{La latinidad como ecumene}

Por lo pronto, reivindicando una americanidad idealizada de raíz clásica greco-latina como hace Enrique Rodó en Ariel (1900), donde dos sistemas culturales antagónicos se enfrentan: el norte agresivo, pragmático y utilitario; el sur, idealista, humanista, heredero de los valores de la latinidad.

32 Citado por J. Edwards, "Pecados literarios", El País, Madrid, 16/12/1984.

33 L. Zea, "Descubrimiento e identidad latinoamericana", Nuestra América; Revista de Occidente, Madrid, 129. 
La "pugna de latinidad contra sajonismo" es el conflicto que Vasconcelos avizora tras la derrota de España en 1898, por lo cual apela en La raza cósmica (1925) a reivindicar la primera. En ese breve ensayo recuerda como la vieja latinidad romana incorporó sin destruirlas razas y culturas, aún imponiendo su hegemonía a pueblos de diversas identidades. Este sentido ecuménico se habría trasladado al Nuevo Mundo, originando la América de nuestros días, donde pueblos diversos encuentran cabida. Los llamados latinos —escribía Vasconcelos- tal vez no son propiamente latinos, sino "un conglomerado de tipos y de razas que persisten en no tomar muy en cuenta el factor étnico (...) Y es en esta fusión de estirpes donde debemos buscar el rasgo fundamental de la idiosincrasia iberoamericana”. En esa latinidad están las raíces de la universalidad americana, esa "quinta raza" que "no excluye, acapara vida", esa "ecumene" encarnada por Roma, la que lejos de excluir pueblos y culturas los incorporó para convertirlos en matriz de múltiples naciones. En esa universalidad geográfica donde se sintetizan las civilizaciones de la India, Grecia, Alejandría y Roma, un mestizaje del que la propia España es ejemplo. Por ello — concluye- América no podrá ser grande "mientras el español de la América no se sienta tan español como los hijos de España. Lo cual no impide que seamos distintos cada vez que sea necesario, pero sin apartarnos de la más alta misión común"34.

En esa misma dirección, Pedro Henríquez Ureña reafirmó en 1926 —en el marco de la exhumación del término Romania y de la "romanidad" llevado a cabo por la escuela de la filología románica - que Hispanoamérica pertenece a "la Romania, la familia románica que constituye todavía una comunidad, una unidad de cultura, descendiente de la que Roma organizó bajo su potestad". Henríquez Ureña sostenía que "pertenecemos como dice la manoseada y discutida fórmula, a la raza latina; otra imagen de raza, no real sino ideal”. Ello explica que como resultado del enfrentamiento entre conquistadores y conquistados surja una América que integra en definitiva lo que no podía seguir separado. En esa herencia de la latinidad forjada por Roma, Leopoldo Zea ratifica, por su parte, esa capacidad de conciliar lo uno con lo diverso, lo concreto con lo múltiple, lo individual con lo plural que caracteriza en buena parte la identidad de Hispanoamérica.

\section{Una herramienta eficaz: el historicismo "orteguiano"}

Sin embargo, el mejor modelo para recentrar el problema y devolverlo a su planteo inicial —una filosofía americana independiente - llegó, paradójicamente, desde Europa. El historicismo ofreció a partir de Dilthey ${ }^{35}$ y su "crítica de la razón histórica" y su investigación sobre "la conciencia histórica", como posteriormente con José Ortega y Gasset, la herramienta para proclamar la

34 J. Vasconcelos, La raza cósmica, México, Espasa Calpe Mexicana, 1985, 19.

35 J. Ferrater Mora publica en la Revista Cubana de Filosofia (La Habana, julio-diciembre 1949) “Dilthey y sus temas fundamentales", donde destaca la importancia del historicismo. 
originalidad, la individualidad, la irreductibilidad del espíritu americano en función de su propia circunstancia de tiempo y de lugar. Si bien el Nuevo Mundo había tendido siempre a reflejar el pensamiento de Europa, a seguirlo y de alguna forma adaptarlo, cuando éste desembocó por su propio curso en el historicismo propició que América se encontrara consigo misma, desarrollara su propia auto-conciencia y su reflexión se hiciera auto reflexión en una común filiación con Alberdi. Por la vía del historicismo europeo América se descubre a sí misma como objeto filosófico, en tanto supone la exaltación de lo concreto e individual, el relieve de los particularismos, la valoración de la experiencia histórica en su originalidad irrepetible, todo ello en función de las circunstancias de tiempo y de lugar.

Ortega y Gasset vino a resolver el problema mostrando la historicidad de la filosofía en dos textos - El tema de nuestro tiempo (1935) y Meditaciones del Quijote - de influencia decisiva, especialmente cuando sostuvo que "pensar es dialogar con la circunstancia" porque no hay ideas eternas, ya que "toda idea está adscrita irremediablemente a la situación o circunstancia frente a la cual representa su activo papel y ejerce su función”. Esta perspectiva que, si por un lado había llevado a una devaluación de la metafísica, por otro supuso una nueva filosofía de lo español más ceñida a la historia, concretamente a la Historia de las Ideas.

Samuel Ramos reconoció esa deuda en Hacia un nuevo humanismo (1940) y en Historia de la filosofía en México (1943) y destacó como la "circunstancia orteguiana” había permitido superar el nacionalismo que amenazaba a México en el fervor de los años que siguieron a su Revolución triunfante.

México debe tener en el futuro una cultura "mexicana"; pero no la concebimos como una cultura original distinta a todas las demás. Entendemos por cultura mexicana la cultura universal hecha nuestra, que viva con nosotros, que sea capaz de expresar nuestra alma. $Y$ es curioso que, para formar esta cultura "mexicana", el único camino que nos queda es seguir aprendiendo la cultura europea ${ }^{36}$.

De ahí surgía la necesidad urgente de cultivar el pensamiento, de practicar la reflexión, donde todo filosofar "debe partir de la aceptación de que somos mexicanos y de que tenemos que ver el mundo bajo una perspectiva única, resultado de nuestra posición en él" ${ }^{37}$.

José Gaos, discípulo de Ortega, al exiliarse en México, descubre la deuda de Ramos con su maestro y de cómo, a través de ella, similares inquietudes se comparten en España y América. La hace suya cuando declara "Nuestra vida es ante todo la vida actual en Hispanoamérica", para entroncar en nombre del historicismo ese "nosotros" americano en el que se incluye en la pertenencia más

36 S. Ramos, "El perfil del hombre y la cultura en México" (1940), Antología de la Filosofía Latinoamericana contemporánea, selección de L. Zea, México, Costa Amic Editor, 1968, 69.

37 Ibid. 
vasta de Occidente: "Nosotros —afirma Gaos en El pensamiento hispanoamericano (1944) - somos ante todo los actuales hispanoamericanos, pero los actuales hispanoamericanos somos parte de los hombres actuales de Occidente y "nosotros" resultamos estos hombres actuales de Occidente". Y concluye: "Occidente, he aquí la primera entidad histórica que debe ocuparnos" (Gaos: 41).

El Occidente de Gaos incluye dos temas capitales de indagación: España y América, a las que une por esa misma condición de objeto y sujeto del filosofar. Porque si América tiene a Bolívar, Sarmiento, Montalvo, Martí, Rodó y Vasconcelos preocupados por la independencia espiritual y cultural de América; España tiene a Quevedo, Gracián, Larra, Joaquín Costa, Ángel Ganivet y, muy especialmente, a la generación del 98, guiados secularmente por esa misma búsqueda. "En suma — sintetiza Gaos- un mismo movimiento de pensamiento, iniciado con la Ilustración en Hispanoamérica, más avanzado en el continente y cuyo extremo rezagado es el pensamiento español más reciente”. En el encabalgamiento de las divisiones históricas, considera que el pensamiento post-independencia del continente y el de la Península se han influido recíprocamente. A través de la pertenencia común en esa perspectiva occidental que desarrolla Gaos como "transterrado", el feliz neologismo con el que se proclama tan español como americano, América no sólo se reconcilia con España, sino que descubre su propia naturaleza.

\section{América, más allá del extremo Occidente}

Para entender la verdadera dimensión de esta apuesta, quisiera en la última parte de este ensayo retroceder al momento del descubrimiento de América para situarme en Europa, donde — después de 1492 - todo cambia, empezando por las mentalidades de la época. La incorporación de América a la historia de Occidente es uno de los mitos fundadores de la historia de la humanidad: la modernidad; acontecimiento que obliga a una nueva representación del cosmos, a reinterpretar el mundo, enorme desafío para la imaginación, la razón y la fe.

El mundo resulta ser más grande de lo que se creía, pero al mismo tiempo se "encoge" a ojos de quienes se lo reparten frente a mapas improvisados. Europa empieza realmente a existir en ese momento ${ }^{38}$. Se va forjando la unidad política, económica y religiosa gracias a la cual adquiere fuerza y coherencia. Se afianza el llamado "espíritu de los descubridores". Los humanistas empiezan a hablar de universalidad, de "Humanidad" — el mundo como la casa del género humanonoción con que se inaugura la modernidad en Occidente. Es bueno subrayar que solo en ese momento Europa se asimila a la idea de Occidente, retomando la vieja división del mundo clásico griego en el Mediterráneo entre Oriente y Occidente. El post 1492 permitió la inversión de perspectivas: es Europa la que se

38 Entrevista con Consuelo Varela, "1492: état des lieux", Magazine littéraire, 296, Paris, febrero 1992. 
descubre a sí misma, lo que parece olvidarse durante los siglos ulteriores en que guerras, guerras de religión y civiles, rampantes nacionalismos la dividen.

Sin embargo, allí estaba el germen de lo que une, más que lo que separa: una Europa con algo de aquel germen que se gestara en los Países Bajos, patria o tierra de retiro de Erasmo, Descartes, Spinoza, Grocio y Huygens, símbolo de una Europa sin tribunal de la Inquisición y rica en tolerancia intelectual, una $\mathrm{Eu}-$ ropa abierta al diálogo entre visiones opuestas del mundo. Lo hace para subrayar la validez del pacto social preconizado por Spinoza, fundador de la racionalidad moderna, al no aceptar, bajo ningún concepto, la renuncia a la libertad individual de juicio y de conciencia.

\section{España, periferia de Europa}

En este proceso se inscriben las relaciones conflictivas que ha tenido la propia España con Europa y el modo como ello ha repercutido en Hispanoamérica. El hecho de que la lengua hablada en el Nuevo Mundo sea mayoritariamente la española, unce América a la cultura ibérica, a su vez subestimada en el seno de Europa. Por mucho que se lo considerara injusto su aislamiento ha sido notorio hasta hace un par de décadas en que España ha sido aceptada en la Unión Europea, a lo que contribuyó la situación política de la península — las largas dictaduras de España y Portugal- y la de los propios países americanos zarandeados por la inestabilidad, militarismo, revoluciones y golpes de estado. La experiencia histórica de América provenía de esa doble herencia ibérica: la española y la portuguesa.

Una experiencia marcada, sin duda, por una alta dosis de asimetrías sociales y autoritarismos políticos —el legado del señorialismo y del patrimonialismo. Pero una experiencia, también, señalada por una gran capacidad de integración cultural. Una herencia, pues, al mismo tiempo de desigualdad y de mezcla, de exclusión y de integración ${ }^{39}$.

A partir de esta comprobación de raíces comunes — desigualdad y mezcla, exclusión e integración- América ha asumido compartir con España un destino periférico, complicidad que ha generado una cierta solidaridad histórica retroactiva. Aquellas "fatalidades" de que hablaba Alfonso Reyes eran también las de España en relación a Europa: la marginación periférica tras la barrera de los Pirineos. Este sentido de marginación se prolongaba en una América que se veía, a su vez, marginada de la modernidad, sumida en esa "barbarie" que adjudicaba Ortega y Gasset a España: "Ciencia bárbara, mística y errabunda ha sido siempre y presumo que lo será, la ciencia española”; irracionalismo y no razón, balbuceo y no definición clara y distinta propia de la ciencia europea, la de los pueblos francos, germanos y sajones ${ }^{40}$. Sin embargo, explicar la "peculiar

39 J. Guilherme Merquior, "El Otro Occidente", Cuadernos Americanos, 13, enero-febrero 1989, México, UNAM, 21.

40 J. Ortega y Gasset, "Crítica bárbara”, Obras completas, vol. I, Madrid, Revista de Occidente, 1946, 44. Para Ortega y Gasset potenciar lo europeo de España suponía potenciar lo germano. 
situación" de España en el contexto europeo y de la cultura de Occidente no resultaba fácil. Lo precisó Américo Castro al resaltar el "crónico descontento" de los españoles, sus "luchas fratricidas, el ciego estallido de furias" que caracterizan su historia. Desde el siglo XIX era posible anotar:

La crisis de una España que se siente fuera de una historia cuyo liderazgo está al otro lado de los Pirineos; crisis de una Hispano-América que se siente al margen de esta misma historia cuya conducción vienen reclamando ya los Estados Unidos de la América Latina al otro lado del Río Bravo ${ }^{41}$.

Mientras el pensamiento español sostenía la necesidad de europeizarse - como ya lo había propuesto Unamuno al invitar a descubrir España, pero a través de Europa, ya que "España está por descubrir y sólo la descubrirán españoles europeizados" 42 - Hispanoamérica seguía inmersa en la disyuntiva de Sarmiento: civilización o barbarie, aunque éste hubiera optado por una civilización cuyo modelo eran los Estados Unidos, para llegar a ser "los yanquis del sur" como preconizó Justo Sierra.

En la propia España las opiniones estaban lejos de ser unánimes. La España con "dos puertas" — respectivamente abiertas a Europa y África — era una casa "mala de guardar", una "isla colocada en la conjunción de dos continentes", escribiría con escepticismo Angel Ganivet. No es extraño que considerara que "las virtudes de la raza española" hubieran degenerado en América" para convertirse en "pecados capitales". Por ello preconizaba "cerrar con cerrojos, llaves y candados, todas las puertas por donde el espíritu español se escapó de España para derramarse por los cuatro puntos del horizonte, y por donde hoy espera que ha de venir la salvación”"33. Concentrar todas las energías dentro del territorio, de eso se trababa.

Por el contrario, la "España peregrina" del exilio, tras la guerra civil española, encontró su otra España en América. Muchos descubrirían la plenitud de la españolidad en el contacto con los pueblos iberoamericanos. Como ha dicho Prat -viejo exilado- descubren a España en América. El gobierno de la República en el exilio se establece en México y, aunque "está" más lejos de España que Francia, "es" infinitamente más España. Juan Ramón Jiménez lo encuentra en Puerto Rico: "Desconfío de mi ahora y desconfío ahora de lo que leo ahora escrito en español de España y fuera de España". Se trata "de perder el español de España y ganar los españoles de América”.

“PPor qué — se pregunta en Meditaciones del Quijote — se obstina anacrónicamente consigo mismo? ¿Por qué se olvida de su herencia germánica?”. Seducido por el racionalismo metafísico germánico, con el cual quiere superar al español mediterráneo: "Yo no soy sólo mediterráneo", exclama.

41 L. Zea, "Hispano-América siglo XIX. Ruptura y reencuentro", Cuadernos Americanos, 19, enero-febrero 1990, México, UNAM, 97.

42 M.de Unamuno, "España y los españoles”, El porvenir de España y los españoles, Madrid, colección Austral, 1973, 117.

43 A. Ganivet, "Idearium español", Obras completas de Angel Ganivet, Madrid, Aguilar, 1943, 217. 
En esta solidaridad en la desgracia, como sucedió décadas después con el exilio político hispanoamericano en España en los años setenta y tal como se vive en la actualidad con la emigración económica, más que la vecindad geográfica, lo importante es la comunidad compartida de una historia, la lengua y la cultura: el "ser histórico-cultural” frente al "estar geográfico" que reivindica José Luis Rubio ${ }^{44}$, sobre cuyas bases justifica esa necesidad de unión, no en razón continental y geográfica, sino en función de valores de profundas raíces identitarias, casi metafísicas: el ser por encima del estar, que aproxima de nuevo el mudo americano al español.

\section{El otro Occidente}

Pero hay más. No debe verse esta comunidad compartida que se reencuentra por otras vías como expresión de una solidaridad entre periféricos que se forja en las últimas décadas, sino — tal vez-algo mucho más importante. América no es el "extremo occidente", sino "el otro occidente" — decía el ensayista brasileño José Guilherme Merquior al recordar que justamente "Portugal y España, los marginados cispirenaicos, fueron la dinámica de Occidente en el alba de los tiempos modernos. La marginación se hizo vanguardia civilizacional. No es la Europa próspera del norte la que se aventura en mares desconocidos, sino la pobre y marginada del sur.

Merquior recordaba que la marcha de la civilización, como el sol, va desde el Oriente hacia el Occidente. América está en esa dirección. "Nuestro trayecto es la misma trayectoria de Occidente. Somos el Otro Occidente: condenados a mediar entre Norte y Sur, geocultural y económicamente, nuestro destino no es resistir a la modernidad. Es, simplemente, modularla" ${ }^{45}$.

La integración es el reto histórico de América. No es ni antítesis de Occidente, ni antítesis de la denostada modernidad, sino una compleja y original "modelación" de la cultura europea, tal vez su mejor — por no decir, utópica- encarnación de sus mejores aspiraciones sociales y humanas. Hijos de la violenta codicia de Europa redimidos por los propios ideales del Viejo Mundo.

Hoy resulta evidente que América tiene ese doble pasado, esa doble herencia: la propia y la de Europa, por lo que no puede prescindir ni de su historia ni de la de Occidente, lo que es justamente el fundamento de su especificidad y el origen de buena parte de sus contradicciones no resueltas. Alienada, cuando no excéntrica a la propia realidad del "país interior", la identidad resultante es plural y su diversidad, la mejor expresión y resumen del mosaico étnico y cultural del mundo, en definitiva de su universalidad. Es la América mestiza, mayoritaria y plural, la que mejor define esta identidad configurada día a día en un proceso de

44 J. L. Rubio, "La España del Siglo XX ante Iberoamérica", Cuadernos Americanos, Marzoabril, 1987, México, UNAM, 97.

45 J. Guilherme Merquior, "E1 otro Occidente", Cuadernos Americanos, 13, enero-febrero, 1989, México, UNAM, 21. 
creación y recreación permanente. No hay una centralidad exclusiva americana, sino que ella es el resultado de un juego de reflejos entre Europa (o si se prefiere la llamada cultura occidental) y América, espejos que se reenvían signos, imágenes, símbolos y mitos complementarios de todo tipo.

En cierto modo - como ya lo dijera Alfonso Reyes en 1936- hablar de "cultura americana es algo equívoco: ello nos haría pensar solamente en una rama del árbol de Europa trasplantada al suelo americano". En cambio, debemos hablar de la inteligencia americana, su visión de la vida y su acción en la vida. Esta visión específica es "el matiz de América", esa "laboriosa entraña de América que va poco a poco mezclando esta sustancia heterogénea" y que forma la "humanidad americana"; una inteligencia que opera en base a disyuntivas ${ }^{46}$.

Arturo Andrés Roig recuerda como Francisco Miranda, a fines del siglo XVIII — en pleno Siglo de las Luces - ya hablaba de la necesidad de lograr una "emancipación mental" que completara la independencia política; de cómo Bolívar se lamentaba de que "nuestras manos están libres y todavía nuestros corazones padecen las dolencias de la servidumbre" y Juan Bautista Alberdi señalaba "rompimos las cadenas mediante las armas, pero nos falta quebrar otras, lo que será obra del pensamiento" 47 . Por ello Roig plantea la necesidad de "una segunda independencia" que complete el proceso iniciado por la primera y rescata la idea de la "emancipación" instaurada por la Ilustración. En esta segunda independencia se debería completar la tarea inconclusa de emancipar el pensamiento, "emancipación mental" de la que dependen los viejos ideales de la democracia participativa hoy amenazados por las formas mas groseras de la racionalidad capitalista. Se trata pues de rescatar la independencia perdida, lo mejor del pensamiento liberal depurado del economicismo capitalista.

Como no es difícil comprobar, la buscada independencia de los primeros pensadores americanos sigue sin resolverse, aunque hoy en día América - ese "otro Occidente" - tenga cosas que decir. Retomando palabras claves de este ensayo: América puede - a través de un género flexible como el ensayo- modular, otorgar matices, proponer partenariados y, sobre todo, hacerlo con esa "inteligencia" que recomendaba el gran polígrafo mexicano.

\section{BIBLIOGRAFÍA}

Adorno, T., Minima Moralia, Caracas, Monte Ávila, 1975.

Aínsa, F., Los buscadores de la utopía, Caracas, Monte Ávila, 1977.

—, Necesidad de la Utopía, Buenos Aires, Tupac-Nordan, 1990.

—, De la edad de oro a El Dorado. Génesis del discurso utópico americano, México, FCE, 1992.

—, La reconstrucción de la utopia, Buenos Aires, Ediciones del Sol, 1998.

46 A. Reyes, "Notas sobre la inteligencia americana", Obras completas de Alfonso Reyes, vol. XI, México, FCE, 1960, 82-83.

47 A. A. Roig, "Necesidad de una segunda Independencia", Santiago de Chile, Polis. Revista académica bolivariana, Volumen 1, 4, 2003. 
Alberdi, J. B., "Ideas para un curso de filosofía contemporánea", Fuentes de la cultura latinoamericana, vol.1, L. Zea, comp., México, FCE, 1993.

Andueza, M., "Trayectoria y función del ensayo hispanoamericano del siglo XX", El ensayo en nuestra América. Para una reconceptualización, Actas del Coloquio Internacional sobre el ensayo en América Latina, México, UNAM, 1993.

Arciniegas, G., "Nuestra América es un ensayo", Con América nace la nueva historia, Bogotá, Tercer Mundo editores, 1991.

Bello, A., Obras completas, vol.VII, Santiago de Chile, 1884.

Bilbao, F., El evangelio americano, Caracas, Biblioteca Ayacucho, 1988.

-, Iniciativa de la América, Latinoamericana. Cuadernos de Cultura latinoamericana, 96, UNAM, 3, 1978.

Briceño Guerrero, J. M., El laberinto de los tres minotauros, Caracas, Monte Ávila, 1994. Reúne: La identificación americana con la Europa segunda (1977), Europa y América en el pensamiento mantuano (1981) y Discurso salvaje (1980).

Bronner, S., Reivindicación de la Ilustración. Hacia una politica de compromiso radical, Pamplona, Laetoli, 2007.

Cerda, M., La palabra quebrada. Ensayo sobre el ensayo, Valparaíso Ediciones Universitarias, 1982.

Cerutti, H., ed., Utopía y nuestra América, Quito, Biblioteca Abya-Yala, 1996

-, América Latina: Democracia, pensamiento y acción. Reflexiones de utopia, México, CCYDEL, Plaza y Valdés, 2003.

—, Utopía en marcha, Quito, Editorial Abya-Ayala, 2009.

Echeverría, E., Dogma socialista de la Asociación de Mayo (Buenos Aires, 1838), Buenos Aires, Cedal, 1979.

Ferrater Mora, J., "Dilthey y sus temas fundamentales", Revista Cubana de Filosofía, La Habana, julio-diciembre 1949.

Ganivet, A.,"Idearium español”, Obras completas de Angel Ganivet, Madrid, Aguilar, 1943.

Loveluck, J., "Esquividad y concreción del ensayo", en El ensayo hispánico, Actas Hispanic Studies, The University of South Carolina, 1984.

Lukacs, G., El alma y las formas, Barcelona, Grijalbo, 1985.

Lyotard, J. F., La condición posmoderna, Madrid, Cátedra, 1987.

Mariátegui, J. C., “¿Existe un pensamiento hispanoamericano?”, en L. Zea, comp., Fuentes de la cultura latinoamericana, vol. II, México, FCE, 1993.

Martí, J., Nuestra América, Caracas, Biblioteca Ayacucho, 1977.

Merquior, J. G., "El otro Occidente", Cuadernos Americanos, 13, enero-febrero 1989, México, UNAM.

Miró Quesada, F., "El impacto de la metafísica en la ideología latinoamericana", Antología de la Filosofía Latinoamericana contemporánea, selección de L. Zea, México, Costa Amic Editor, 1968.

Montiel, E., El humanismo americano. Filosofía de una comunidad de naciones, Lima, FCE, 2000.

Morse, R., El espejo de Próspero, México, Siglo XXI, 1982.

Morales, S., "El ensayo revolucionario: José Marti”", en El ensayo en nuestra América. Para una reconceptualización, México, UNAM, 1993. 
Murena, H. A., El pecado original de América, Buenos Aires, Sur, 1954.

Ortega y Gasset, J., "Crítica bárbara”, Obras completas, vol. I, Madrid, Revista de Occidente, 1946.

Picón Salas, M., Crisis, cambio, tradición. Ensayos sobre la forma de nuestra cultura, Madrid/Caracas, Edime, 1955.

—, La conquista del amanecer, La Habana, Casa de las Américas, 1992.

Ramos, S., "El perfil del hombre y la cultura en México", Antología de la Filosofía Latinoamericana contemporánea, selección de L. Zea, México, Costa Amic Editor, 1968.

Reyes, A., "Notas sobre la inteligencia americana", Obras completas de Alfonso Reyes, XI, México, FCE, 1960.

Rodríguez, S., Inventamos o erramos, Caracas, Monte Ávila, 1980.

- Sociedades americanas, Caracas, Biblioteca Ayacucho, 150, 1990.

Roig, A. A., Ética del poder y moralidad de la protesta. Respuestas a la crisis moral de nuestro tiempo, Mendoza, Universidad de Cuyo, 2002.

- Necesidad de una segunda Independencia, Santiago de Chile, Polis. Revista académica bolivariana, Volumen 1, 4, 2003.

Rojas, R., Eurindia: ensayo de estética sobre las culturas americanas Buenos Aires, Cedal, 1980.

Rubio, J. L., "La España del Siglo XX ante Iberoamérica”, Cuadernos Americanos, marzoabril 1987, México, UNAM.

Unamuno, M. de, "España y los españoles”, El porvenir de España y los españoles, Madrid, Austral, 1973.

Uslar Pietri, A., La isla de Robinsón, Barcelona, Seix-Barral, 1981.

Todorov, T., L'Esprit des Lumières, París, Robert Laffon, 2006.

Torres, C. A., Idola Fori, México, Latinoamericana. Cuadernos de Cultura latinoamericana, 96, UNAM, 1979.

Vasconcelos, J., La raza cósmica, México, Espasa Calpe Mexicana, 1985.

VV. AA., El ensayo en nuestra América. Para una reconceptualización, Actas del Coloquio Internacional sobre el ensayo en América Latina, México, UNAM, 1993.

ZEA, L., "Hispano-América siglo XIX. Ruptura y reencuentro", Cuadernos Americanos, 19, enero-febrero 1990, México, UNAM,

— "Descubrimiento e identidad latinoamericana”, Nuestra América; Revista de Occidente, Madrid, 1970. 